\title{
Location and Function of fruC, a Gene Involved in the Regulation of Fructose Utilization by Escherichia coli
}

\author{
By HANS L. KORNBERG* AND CHRISTOPHER M. ELVIN† \\ Department of Biochemistry, University of Cambridge, \\ Tennis Court Road, Cambridge CB2 1QW, UK
}

(Received 19 May 1986; revised 9 September 1986)

\begin{abstract}
Procedures are described for the selection of Escherichia coli mutants that constitutively take up and phosphorylate fructose, and convert it to fructose 1,6-bisphosphate. The phenotype of such mutants is described. The altered regulatory gene, $f r u C$, is highly co-transducible with leu and other markers located at min 2 on the genome. In merozygotes, fruC $\mathrm{C}^{+}$is dominant to fruC. Mutants can be readily isolated that are $f r u C$ at $42{ }^{\circ} \mathrm{C}$ but $f r u C^{+}$at $30^{\circ} \mathrm{C}$; moreover, the integration of a $\mathrm{Tn} 10$ transposon in the genome at min 2 converts $f r u C^{+}$strains to fruC. It is therefore likely that the $f r u C^{+}$regulatory gene specifies a repressor protein.
\end{abstract}

\section{INTRODUCTION}

The proteins that catalyse the predominant route for the uptake and catabolism of fructose by Escherichia coli are specified by genes located at min 45.8 on the linkage map of this organism (Bachmann, 1983). These include $p t s F$, which codes for the membrane-bound fructose-specific component of the phosphoenolpyruvate-dependent phosphotransferase system (Fraenkel, 1968; Ferenci \& Kornberg, 1971 a, 1974); fpr, which specifies the carrier protein that mediates the transfer of phosphate from Enzyme I to a membrane-associated protein factor III fru (Waygood, 1980; Kornberg, 1986); a gene for the factor III fru (Waygood et al., 1984); and fpk, which specifies the fructose-1-phosphate kinase catalysing the ATP-dependent phosphorylation of the fructose 1-phosphate, formed in the uptake process, to fructose 1,6-bisphosphate (Fraenkel, 1968; Ferenci \& Kornberg, 1973; Jones-Mortimer \& Kornberg, 1974). These genes are inducible and are normally not expressed to any significant extent unless fructose is present in the external medium (Kornberg \& Reeves, 1972) or unless the organism is $f p k$ (Ferenci \& Kornberg, 1973).

A clue to the control of this selective expression of genetic potential was first obtained by Reiner (1977). In the course of a study of pentitol catabolism in a variety of bacteria, he noted that the growth of wild-type strains of $E$. coli was not inhibited by xylitol but that of some mutants was. These latter mutants were also found to be capable of taking up fructose constitutively: abolition of Enzyme I activity by introduction of $p t s I$, or introduction of the ptsF gene, abolished both the uptake of fructose and the inhibitory effect of xylitol. The gene that conferred upon $E$. coli the constitutivity of fructose uptake was highly co-transducible with ara and $l e u$ and was thus located at about min 2 on the linkage map, diametrically opposite to the fructose structural gene cluster.

It is the main aim of the present paper to describe some general procedures for the selection of $E$. coli mutants constitutive for the uptake and utilization of fructose, the phenotype of such mutants, and the more precise location of the regulatory gene $(\mathrm{fruC})$. We also present evidence that $\mathrm{rruC}^{+}$specifies a repressor protein.

$\dagger$ Present address : Research School of Chemistry, Australian National University, Canberra City ACT 2601, Australia. 
Table 1. Organisms used in this study

Strain

Genotype

JM1569 $\mathrm{F}^{-} p t s M$ pfkA gnd fdp umgC

HK743 $\mathrm{F}^{-}$ptsM umgC arg thr leu rpsL

HK820 $\mathrm{F}^{-}$ptsH ptsM ptsG argE thr rpsL

HK $1099 \mathrm{~F}^{-}$ptsH pts $M$ ptsG fruC argE thr rpsL

CE71 Hfr-KL16 ptsM leu::Tn5

CE78 $\mathrm{F}^{-}$ptsM pfkA gnd fdp fruC umgC

CE91 Hfr-KL16 ptsM fruC

CE97 $\mathrm{F}^{-}$ptsM gnd fdp umgC met $B$

CE216 F F $^{-}$ptsM umgC fruC arg thr rpsL

CE217 $\mathrm{F}^{-}$ptsM umgC arg thr rpsL

CE218

LA5610 $\mathrm{F}^{-}[\arg F-l a c]^{\Lambda} U 169$ araD139 relA1 deoCl ptsF25 febB5301 rpsL150 Tn10::zab

$\mathrm{F}^{\prime} 101 \quad \mathrm{~F}^{+}$thr $r^{+}$leu $/$thr leu pro his argE thi recA rpsL
Provenance

Gift from Dr M. C. Jones-Mortimer

Laboratory stock

Laboratory stock

Sorbitol ${ }^{+}$pseudo-revertant of HK 820

Sorbitol ${ }^{+}$pseudo-revertant of JM1569

Leu $^{+}$xylitol $^{\mathrm{s}}$ transductant; P1 (CE78) $\times$ CE71

Pl ( $p f k A^{+}$metB) transductant of JM1569

$\mathrm{Leu}^{+}$xylitol $^{\mathrm{s}}$ transductant, P1 (CE91) $\times$ HK743

Leu $^{+}$xylitol ${ }^{r}$ transductant, P1 (CE97) $\times$ HK743

Tetracycline ${ }^{\mathrm{r}}$, rec $A$ transductant, $\mathrm{Pl}$

$(\operatorname{srl} A:: \operatorname{Tn} 10) \times \mathrm{CE} 216 \mathrm{rec} A$

Gift from Dr W. Boos

Gift from Dr B. Bachmann (CGSC 4250)

\section{METHODS}

Organisms, media and experimental procedures. The organisms used in this study are listed in Table 1 . They were grown either on double-strength nutrient broth (Oxoid, code CM1) or on defined media, containing salts (Ashworth \& Kornberg, 1966), any amino acids required (at $40 \mu \mathrm{g} \mathrm{ml}^{-1}$ ), and appropriate carbon sources at 5 or $10 \mathrm{~mm}$ final concentrations. Cells were grown aerobically at temperatures specified in the text, either as $10 \mathrm{ml}$ cultures in $50 \mathrm{ml}$ capped Erlenmeyer flasks, shaken in a reciprocal shaking water bath at 110 oscillations $\mathrm{min}^{-1}$, or in larger quantities, in a New Brunswick orbital incubator shaker. The cells were harvested and used for further experiments involving measurements of growth rates, of effects of inhibitors thereon, or of the uptake of ${ }^{14} \mathrm{C}$ labelled substrates, as described by Amaral \& Kornberg (1975). Phage P1 were grown and used for transductions as described by Miller (1972). Fructose-1-phosphate kinase activity was measured by the procedure of Ferenci \& Kornberg (1973). Other procedures are described in the text or in the legends to tables. The genetic markers are those listed by Bachmann (1983) except where otherwise defined.

\section{RESULTS AND DISCUSSION}

\section{Selection of fruC mutants}

Mutants of $E$. coli devoid of the histidine-protein HPr $(p t s H)$ do not grow on any sugar taken up via the PT-system with the exception of fructose (Saier et al., 1970, 1976; Bolshakova et al., 1979). When a pts $H$ mutant (HK820), that also lacked the Enzymes II for glucose (ptsG) and for mannose $(p t s M)$, was spread on plates containing either of the PT-sugars sorbitol or $\mathrm{N}$ acetylglucosamine as sole carbon source, secondary mutants arose (with a frequency that approached $1 \times 10^{-6}$ ), that now grew equally well on either substrate. The overwhelming majority of such secondary mutants are not revertants to $p t s H^{+}$: phage $\mathrm{Pl}$ grown on them still readily transduce $c y s A$ pts $H^{+}$recipients to $c y s A^{+} p t s H$. Nor have they been altered in any gene located close to the genes specifically involved in fructose uptake and utilization, which comprise the cluster $p t s F, f p k$ and $f p r$ at min $45 \cdot 8$ on the $E$. coli genome (Jones-Mortimer \& Kornberg, 1974). Rather is the change in the organisms' ability to grow on PT-sugars, in the absence of HPr function, associated with a region of the genome $(\mathrm{fruC})$ that is highly cotransducible with leu and that specifies not only the uptake of fructose (Reiner, 1977) but also other components of the system for fructose utilization. Since the overall conversion of fructose to fructose 1-phosphate is expressed constitutively by such fruC mutants (Table 2), FPr is also synthesized in amounts much greater than normal by them: it can now assume the carrier functions usually performed by HPr and thus permit pts $H$ pts $M$ strains of $E$. coli to grow on PTsugars that would otherwise not be utilized.

This mode of selecting fruC-mutants is not confined to pts $H$ parents, but applies to any circumstance in which the uptake and utilization of a PT-sugar is prevented by a block that could be circumvented by an alteration in a regulatory gene. For example, the $E$. coli strain 
Table 2. Fructose uptake by gluconate-grown cells, and activities concerned with fructose utilization in cell-free extracts thereof

The overall activity of the fructose PTS was assayed in cells rendered permeable with toluene as described by Kornberg \& Reeves (1972), and fructose-1-phosphate kinase by the procedure of Ferenci \& Kornberg (1973). The amount of $\left[{ }^{14} \mathrm{C}\right]$ fructose 1 -phosphate formed from $0 \cdot 1 \mathrm{~mm}-\left[{ }^{14} \mathrm{C}\right]$ fructose by extracts of the cells, supplemented with phosphoenolpyruvate and Enzyme I, was assayed essentially as described by Waygood et al. (1979). The uptake of fructose by washed suspensions of whole cells was measured as outlined by Amaral \& Kornberg (1975).

\begin{tabular}{|c|c|c|c|c|}
\hline \multirow[b]{2}{*}{ Strain } & \multicolumn{3}{|c|}{ Activity $\left[\mathrm{nmol} \mathrm{min}^{-1}(\mathrm{mg} \text { protein })^{-1}\right]$} & \multirow[b]{2}{*}{$\begin{array}{c}\text { Fructose uptake } \\
\text { by whole cells } \\
\text { [nmol min }{ }^{-1} \\
\left.\text { (mg dry mass) })^{-1}\right]\end{array}$} \\
\hline & $\begin{array}{l}\text { Fructose } \\
\text { PTS }\end{array}$ & $\begin{array}{l}\text { Fructose- } \\
\text { 1-phosphate } \\
\text { kinase }\end{array}$ & $\begin{array}{l}{\left[{ }^{14} \mathrm{C}\right] \text { Fructose }} \\
\text { phosphorylation }\end{array}$ & \\
\hline $\begin{array}{l}\text { HK820 }\left(\text { fru } C^{+}\right) \\
\text {HK } 1099(\text { fruC })\end{array}$ & $\begin{array}{l}<1 \\
69\end{array}$ & $\begin{array}{r}5 \\
760\end{array}$ & $\begin{array}{l}<1 \\
50\end{array}$ & $\begin{array}{l}1 \cdot 5 \\
10\end{array}$ \\
\hline
\end{tabular}

JM1569 carries the relevant markers $p f k A$, gnd, $f d p, p t s M$; it is constitutive for the uptake of glucose via the PtsG system (umgC) (Kornberg \& Reeves, 1972). Because of the absence of fructose 6-phosphate kinase ( $p f k A)$, catabolism of glucose or of other precursors of fructose 6phosphate via the Embden-Meyerhof pathway cannot occur; the absence of 6-phosphogluconate dehydrogenase $(g n d)$ also prevents utilization of such sugars via the pentose phosphate pathway. Furthermore, the lack of fructose-1,6-bisphosphatase activity $(f d p)$ prevents gluconeogenesis from fructose (Ferenci \& Kornberg, 1971b; Jones-Mortimer \& Kornberg, 1974). In theory, growth on fructose could occur only if a precursor of fructose 6-phosphate (such as glucose) were simultaneously provided to the cell, but this is not possible in practice since glucose and other precursors of glucose 6-phosphate powerfully inhibit the uptake of fructose (Kornberg, 1972; 1973; Amaral \& Kornberg, 1975), especially if the organisms take up glucose constitutively $(u m g C)$. There is thus no growth on fructose, on glucose, or on mixtures of the two. However, secondary mutants arise, on plates containing the mixture of both hexoses, that still cannot grow upon either fructose or glucose alone, or on other precursors of glucose 6-phosphate (such as $\mathrm{N}$-acetylglucosamine) supplied as sole carbon sources. And, again, such mutants are constitutive for the uptake and utilization of fructose; again, phage P1 grown on them can cotransduce with over $60 \%$ linkage this altered regulation and the leu marker.

As was shown by Reiner (1977), mutants that express constitutively the Enzyme II for fructose uptake can be readily distinguished from their parent, $f \mathrm{ruC} \mathrm{C}^{+}$, organisms by their sensitivity to xylitol. This is a pentitol not utilized for growth by E. coli, that is not an inducer of the Enzyme II for fructose uptake but that can be taken up by cells previously exposed to fructose. Using the assay procedure of Kornberg \& Reeves (1972), it can be readily shown that cells constitutive for fructose uptake also take up and phosphorylate xylitol constitutively. Toluene-treated suspensions of the $\mathrm{fruC}^{+}$strain $\mathrm{CE} 217$, grown on gluconate, effected the PEP-dependent phosphorylation of only $0.8 \mathrm{nmol}$ xylitol $\mathrm{min}^{-1}\left(\mathrm{mg}\right.$ dry mass) ${ }^{-1}$, whereas those of the otherwise isogenic fruC strain CE216 phosphorylated over $50 \mathrm{nmol} \mathrm{min}^{-1}$ (mg dry mass) ${ }^{-1}$ under identical conditions. Since xylitol 5-phosphate is not catabolized by $E$. coli, the accumulation of this ester would, as commonly noted also with other phosphate esters (Kurahashi \& Wahba, 1958; Englesberg et al., 1962; Cozzarelli et al., 1965; Böck \& Neidhardt, 1966; Solomon \& Lin, 1972; Kornberg, 1972; Ferenci \& Kornberg, 1973), effectively inhibit growth, probably by a general inhibition of membrane transport (Kornberg, 1973). Although we did not identify the pentitol ester formed from PEP and xylitol as the 5-phosphate, this is likely by analogy with Lactobacillus spp., which also take up xylitol via the PT-system and have been shown to form xylitol 5phosphate (London \& Hausman, 1982).

\section{Catabolite regulation in fruC mutants}

The utilization of fructose (and other substrates of the PT-system) by fruC $\mathrm{C}^{+}$strains of $E$. coli is affected by the presence of glucose in two main ways. When glucose is added to washed 
Table 3. Fraction $(\%)$ of total carbon derived from each of two carbohydrates by strains of E. coli growing on mixtures of them

The relative utilization of the two hexoses was measured as the rate of incorporation of isotope from $5 \mathrm{mM}-\left[{ }^{14} \mathrm{C}\right]$ substance $A$ by cells growing on it in the presence of unlabelled $5 \mathrm{~mm}$-substance $\mathrm{B}$, and vice versa, as described by Amaral \& Kornberg (1975).

\begin{tabular}{|c|c|c|c|c|}
\hline \multirow[b]{2}{*}{ Strain } & \multicolumn{2}{|c|}{ Components of mixture } & \multicolumn{2}{|c|}{$\begin{array}{c}\text { Fraction }(\%) \text { of total cellular carbon } \\
\text { derived from }\end{array}$} \\
\hline & $\mathrm{A}$ & B & A & B \\
\hline CE217 $\left(\right.$ fruC $\left.^{+}\right)$ & $\begin{array}{l}\text { Glucose } \\
N \text {-Acetylglucosamine } \\
\text { Glucose } \\
\text { Sorbitol }\end{array}$ & $\begin{array}{l}\text { Sorbitol } \\
\text { Sorbitol } \\
\text { Fructose } \\
\text { Fructose }\end{array}$ & $\begin{array}{l}95 \\
94 \\
85 \\
53\end{array}$ & $\begin{array}{r}5 \\
6 \\
15 \\
47\end{array}$ \\
\hline CE216 (fruC) & $\begin{array}{l}\text { Glucose } \\
N \text {-Acetylglucosamine } \\
\text { Glucose } \\
\text { Sorbitol }\end{array}$ & $\begin{array}{l}\text { Sorbitol } \\
\text { Sorbitol } \\
\text { Fructose } \\
\text { Fructose }\end{array}$ & $\begin{array}{r}93 \\
95 \\
12 \\
4\end{array}$ & $\begin{array}{r}7 \\
5 \\
88 \\
96\end{array}$ \\
\hline
\end{tabular}

suspensions of fructose-grown cells taking up $\left[{ }^{14} \mathrm{C}\right]$ fructose, the glucose is taken up preferentially even though the cells had not previously been exposed to that hexose: this effect has been designated 'catabolite inhibition' (McGinnis \& Paigen, 1969, 1973; Kornberg, 1972). A second effect is seen when glucose is added to cells growing on another PT-substrate. Growth now continues largely at the expense of the added glucose (Kornberg, 1972, 1973): this preferential use of glucose is an example of 'catabolite repression' (Magasanik, 1961).

Both these types of regulatory behaviour appear not to apply to the uptake of fructose by fruC mutants. Thus, whereas the presence of $1 \mathrm{~mm}$-glucose reduced the initial rate of uptake of $0.1 \mathrm{mM}-\left[{ }^{14} \mathrm{C}\right]$ fructose by the $f r u C^{+}$strain CE217 to less than $8 \%$ of that observed in its absence, glucose reduced fructose uptake by the $f r u C$ strain $\mathrm{CE} 216$ only slightly. Furthermore, cultures of $f r u C$ strains take up fructose at high rates irrespective of the carbon source on which they are grown: in one experiment, the quantities (nmol) of fructose taken up [ $\mathrm{min}^{-1}\left(\mathrm{mg} \mathrm{dry} \mathrm{mass}^{-1}\right]$ by suspensions of strain CE216 were 29 on fructose, 18 on glucose 6-phosphate, 18 on casein hydrolysate, 17 on gluconate, 17 on $\mathrm{N}$-acetylglucosamine and 21 on glucose. The last of these data indicates also that, in $f r u C$ mutants, glucose is likely not to exclude fructose. This is confirmed by the results of Table 3 , which also illustrate the specific effects of the fruC mutation on the 'pecking order' in which mixtures of sugars are used. In contrast to fru $C^{+}$strains, fruC mutants utilize fructose in preference to any other carbohydrate also present. However, they retain the preference, seen in $\mathrm{fruC}^{+}$strains, for glucose to sorbitol, or of $\mathrm{N}$-acetylglucosamine to sorbitol. As expected from these data, the growth of $\mathrm{fruC}$ strains is inhibited by noncatabolizable glucose analogues, such as 3-deoxy-3-fluoro-D-glucose, 5-thio-D-glucose, 2-deoxyD-glucose and methyl $\alpha$-D-glucoside, on media containing sorbitol or carbon sources taken up by active transport, but (in contrast to $\mathrm{fruC}^{+}$strains: Kornberg, 1972) not on fructose.

\section{The nature of the fruC mutation}

The lack of control of the fructose gene cluster that is observed in fru $\mathrm{C}$ mutants could be due to an alteration in either a positive or a negative regulatory system. The evidence we have obtained strongly favours the latter alternative.

(a) In partial diploids, $f r u C^{+}$is dominant to $f r u C$. This was demonstrated by introducing the $\mathrm{F}^{\prime}$-plasmid 101, which carries the wild-type $f r u \mathrm{C}^{+}$and $t h r^{+}$alleles, into the fruC strain CE218, which also carried the $t h r$ gene and, in addition, was $r e c A$. All of $280 t h r^{+} / t h r$ transconjugants thus obtained (selected on plates not containing threonine), were found to be resistant to xylitol, in contrast to the $f r u C$ recipient CE218. Twelve of these transconjugants were purified by the isolation of single colonies, and were grown overnight in nutrient broth in the presence of acridine orange $\left(10 \mu \mathrm{g} \mathrm{ml}^{-1}\right)$ to effect liberation of the episome (Miller, 1972). The cultures were screened for organisms that had regained the threonine requirement of strain CE218. All of nine 
colonies thus shown to be $t h r$ were also now unable to grow on nutrient agar in the presence of xylitol. These results accord with the view that the fruC $\mathrm{C}^{+}$allele, which is thereby shown to be dominant to $f r u C$, specifies a repressor protein which, in the absence of an inducer of the fructose uptake system, normally functions to prevent transcription of the structural genes in the cluster located at min 45.8 on the $E$. coli genome.

(b) This view is supported also by the isolation of mutants that are $f r u C$ at $42{ }^{\circ} \mathrm{C}$ but are $f r u C^{+}$ at $30^{\circ} \mathrm{C}$. When suspensions of strain $\mathrm{HK} 820\left(\mathrm{ptsH} \mathrm{fruC} \mathrm{C}^{+}\right)$were spread on agar plates containing $5 \mathrm{~mm}$-sorbitol as sole carbon source and incubated at $42^{\circ} \mathrm{C}$, isolated colonies appeared as usual after 2-3 d. About $90 \%$ of these secondary mutants grew on sorbitol both at $30^{\circ} \mathrm{C}$ and at $42{ }^{\circ} \mathrm{C}$, and were strongly inhibited by $2 \mathrm{~mm}$-xylitol at either temperature. However, approximately $10 \%$ of the secondary mutants grew on sorbitol only at the elevated temperature and not (overnight) at $30^{\circ} \mathrm{C}$; moreover, whereas they were sensitive to xylitol at $42{ }^{\circ} \mathrm{C}$ they were impervious to the pentitol at $30^{\circ} \mathrm{C}$. As demonstrated by phage-mediated transduction, the change in these temperature-sensitive mutants resided in the fruC gene: phage $\mathrm{P} 1$ grown on them and used to transduce a leu fru $\mathrm{C}^{+}$recipient also produced the temperature-sensitive $\mathrm{FruC}-$ phenotype in about $66 \%$ of transductants selected for $\mathrm{Leu}^{+}$.

(c) Further evidence in favour of a negative regulatory system came from study of the properties of organisms into which a Tn 10 transposon had been inserted at $\min 2$ on the genome. Phage P1 grown on a strain of E. coli, LA5610 (described as $z a b:$ : Tn 10 by Benner et al., 1985) readily effected the transduction of leu recipients to $l e u^{+}$: approximately $60 \%$ of such transductants had also become $f r u C$. However, and more important, all the transductants that were $f r u C$ were now also resistant to tetracycline, and all that had been selected directly for the Tn 10 transposon, on nutrient plates containing tetracycline $\left(20 \mu \mathrm{g} \mathrm{ml}^{-1}\right)$, were fruC. Such transductants apparently did not give rise to revertants: it is likely that the transposon was actually integrated into the $f r u C^{+}$gene and that this thereby prevented the synthesis of the repressor protein specified by that gene. Since phage carrying this transposon could also effect with $80 \%$ efficiency the simultaneous transfer of the $f t s A$ and $\sec A$ markers located at min 2 on the genome of $E$. coli (Benner $e t$ al., 1985), these results not only show that the location of the transposon would more accurately be described as zac: : Tn 10 but they also locate the fruC gene at this position on the $E$. coli linkage map.

While this paper was being written, we received from Dr P. Postma (University of Amsterdam) a pre-print of an article submitted for publication in another journal (Geerse et al., 1986). That paper reported, inter alia, the location of the regulatory locus, there termed fruR, close to leu on the Salmonella typhimurium genome, and between leu and $p b p B$ on the E. coli linkage map. The relevant regions from both organisms were cloned on plasmids and expressed in maxicells: they specified a polypeptide of approximate $M_{\mathrm{r}} 36000$. These findings complement and extend ours, and substantiate the view that the gene we designate $f r u C^{+}$normally specifies a repressor protein.

We thank Mr C. R. Denston for skilled technical assistance, Professor W. Boos and Dr M. C. Jones-Mortimer for gifts of $E$. coli strains and for much helpful advice, and Dr P. Postma for sending us a pre-print of the work of his group. This work was done during the tenure by C. M. E. (1979-1982) of a George Murray Scholarship from the University of Adelaide. It was supported initially by the Science and Engineering Research Council under Grant GR/C 97286 and subsequently by a generous personal grant-in-aid to H. L.K. from Unilever Research Ltd.

\section{REFERENCES}

AMARAL, D. \& Kornberg, H. L. (1975). Regulation of fructose uptake by glucose in Escherichia coli. Journal of General Microbiology 90, 157-168.

AshworTh, J. M. \& Kornberg, H. L. (1966). The anaplerotic fixation of carbon dioxide by Escherichia coli. Proceedings of the Royal Society B165, 179-188.

BaCHMANN, B. J. (1983). Linkage map of Escherichia coli K-12, edition 7. Microbiological Reviews 47, 180230 .
Benner, D., Muller, N. \& Boos, W. (1985). Temperature-sensitive catabolite activator protein in Escherichia coli BUG 6. Journal of Bacteriology 161, 347-352.

Böck, A. \& Neidhardt, F. C. (1966). Properties of a mutant of Escherichia coli with a temperaturesensitive fructose 1,6-diphosphate aldolase. Journal of Bacteriology 92, 470-476.

Bolshakova, T. N., DobRynina, O. Y. \& 
GERSHANOVITCH, V. N. (1979). Isolation and investigation of the Escherichia coli mutant with the deletion in the pts $H$ gene. FEBS Letters 107, 169172.

Cozzarelli, N. R., Koch, J. P., Hayashi, S. \& Lin, E. C. C. (1965). Growth stasis by accumulated L- $\alpha-$ glycerophosphate in Escherichia coli. Journal of Bacteriology 90, 1325-1329.

Englesberg, E., Anderson, R. L., WeinberG, R., Lee, N., Hoffee, P., Huttenhauer, G. \& Boyer, H. (1962). L-Arabinose-sensitive, L-ribulose 5-phosphate 4-epimerase-deficient mutants of Escherichia coli. Journal of Bacteriology 84, 137-146.

FERENCI T. \& Kornberg, H. L. (1971a). Pathway of fructose utilization by Escherichia coli. FEBS Letters 13, 127-130.

FERENCI, T. \& KornberG, H. L. (1971 b). Role of fructose 1,6-diphosphatase in fructose utilization by Escherichia coli. FEBS Letters 14, 360-364.

FerenCI, T. \& KorNBERG, H. L. (1973). The utilization of fructose by Escherichia coli. Properties of a mutant defective in fructose 1-phosphate kinase activity. Biochemical Journal 132, 341-347.

Ferenci, T. \& Kornberg, H. L. (1974). The role of phosphotransferase-mediated syntheses of fructose 1 -phosphate and fructose 6-phosphate in the growth of Escherichia coli on fructose. Proceedings of the Royal Society B187, 105-119.

FraENKel, D. G. (1968). The phosphoenolpyruvateinitiated pathway of fructose metabolism in Escherichia coli. Journal of Biological Chemistry 243, 64586463.

Geerse, R. H., Ruig, C. R., Schuitema, A. R. J. \& Postma, P. (1986). Relationship between pseudo$\mathrm{HPr}$ and the PEP:fructose phosphotransferase system in Salmonella typhimurium and Escherichia coli. Molecular and General Genetics 203, 435-444.

JONES-MORTIMER, M. C. \& KORNBERG, H. L. (1974). Genetical analysis of fructose utilization by Escherichia coli. Proceedings of the Royal Society B187, 121131.

KORNBERG, H. L. (1972). Nature and regulation of hexose uptake by Escherichia coli. In The Molecular Basis of Biological Transport, pp. 157-180. Edited by J. W. Woessner, Jr \& F. Huijing. New York \& London: Academic Press.

KORNBERG, H. L. (1973). Fine control of sugar uptake by Escherichia coli. Symposia of the Society for Experimental Biology 27, 175-193.

KORNBERG, H. L. (1986). The roles of HPr and FPr in the utilization of fructose by Escherichia coli. FEBS Letters 194, 12-15.

KoRnBerg, H. L. \& ReEves, R. E. (1972). Inducible phosphoenolpyruvate-dependent hexose phospho- transferase activities in Escherichia coli. Biochemical Journal 128, 1339-1344.

KURAHASHI, K. \& WaHBA, A. J. (1958). Interference with growth of certain Escherichia coli mutants by galactose. Biochimica et biophysica acta 30, 298-302.

LoNDON, J. \& HAusman, S. (1982). Xylitol-mediated transient inhibition of ribitol utilization by Lactobacillus casei. Journal of Bacteriology 150, 657-661.

MAGASANIK, B. (1961). Catabolite repression. Cold Spring Harbor Symposia on Quantitative Biology 26, 249-254.

McGinnis, J. F. \& Paigen, K. (1969). Catabolite inhibition: a general phenomenon in the control of carbohydrate utilization. Journal of Bacteriology 100 , 902-913.

MCGinnis, J. F. \& PAIGEN, K. (1973). Site of catabolite inhibition of carbohydrate metabolism. Journal of Bacteriology 114, 885-887.

MilleR, J. H. (1972). Experiments in Molecular Genetics. Cold Spring Harbor, NY: Cold Spring Harbor Laboratory.

REINER, A. M. (1977). Xylitol and D-arabitol toxicities due to derepressed fructose, galactitol and sorbitol phosphotransferases of Escherichia coli. Journal of Bacteriology 132, 166-173.

Saier, M. H., Simoni, R. D. \& Roseman, S. (1970). The physiological behaviour of Enzyme I and heat-stable protein mutants of a bacterial phosphotransferase system. Journal of Biological Chemistry 245, 58705873.

Saier, M. H., Simoni, R. D. \& Roseman, S. (1976). Sugar transport. Properties of bacteria defective in proteins of the phosphoenolpyruvate :sugar phosphotransferase system. Journal of Biological Chemistry 251, 6584-6597.

Solomon, E. \& Lin, E. C. C. (1972). Mutations affecting the dissimilation of mannitol by Escherichia coli K-12. Journal of Bacteriology 111, 566-574.

WAYGOOD, E. B. (1980). Resolution of the phosphoenolpyruvate:fructose phosphotransferase system of Escherichia coli into two components: enzyme II fructose and fructose-induced HPr-like protein (FPr). Canadian Journal of Biochemistry 58, 1144 1146.

Waygood, E. B., Meadow, N. D. \& Roseman, S. (1979). Modified assay procedure for the phosphotransferase system in enteric bacteria. Analytical Biochemistry 95, 293-304.

Waygood, E. B., Mattoo, R. L. \& Peri, K. G. (1984). Phosphoproteins and the phosphoenolpyruvate: sugar phosphotransferase system in Salmonella typhimurium and Escherichia coli. Evidence for III Mannose,

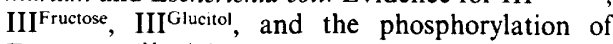
Enzyme II Mannitol and Enzyme II ${ }^{\text {-Acetylglucosamine. }}$ Journal of Cellular Biochemistry 25, 139-159. 